Differentiation of positive results based on consistency of alleged/suspected substance of use

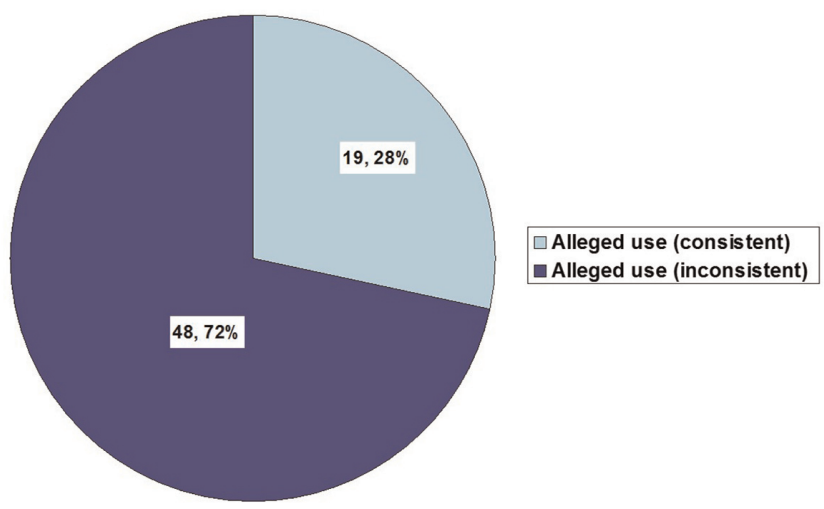

Abstract P0-0659 Figure 2 Differentiation of positive results based on consistency of alleged/suspected substance of use

Objectives 1) Establish prevalence in L\&D Hospital.

2) Establish outcomes of urine toxicology (chain of custody in place) and implication on management.

3) Establish transparency in drug users regarding information of drug use.

Methods Retrospective collection of urine toxicology requests to chemical pathology from Feb 2009 to Oct 2012. Requests were based on self-revelation of drug use by pregnant women and of those suspected during antenatal follow up. Data collection using antenatal database (CMIS), South England neonatal database (SEND) and pathology request database, ensuring no loss of data. Results Total requests: 106. 37\% were negative (Some may represent false negatives). Out of $63 \%$ positive results, $54 \%$ were multidrug users. $72 \%$ positive results were not consistent with the substance of use suggested or suspected. None with negative results withdrew and discharged in 2-3 days once results available reducing length of stay. $40 \%$ Pregnant on methadone program. Only $11 \%$ had an employment or were students. $70 \%$ women were single or separated and $25 \%$ didn't disclose their marital status. 19\% required treatment.

\section{P0-0660 PAIN MANAGEMENT AROUND NECROTIZING ENTEROCOLITIS SURGERY:TOWARDS EVIDENCE-BASED GUIDELINES}

${ }^{1} \mathrm{NJ}$ Meesters, ${ }^{2} \mathrm{M}$ van Dijk, ${ }^{1} \mathrm{DW}$ Roofthooft, ${ }^{1} \mathrm{SH}$ Simons. ${ }^{1}$ Pediatrics Division of Neonatology, Erasmus MC-Sophia Children's Hospital, Rotterdam, Netherlands, ${ }^{2}$ Pediatrics and Pediatric Surgery, Erasmus MC-Sophia Children's Hospital, Rotterdam, Netherlands

\subsection{6/archdischild-2014-307384.1301}

Background and aims Necrotizing entero colitis (NEC) is an extremely painful complication in premature neonates. To our knowledge there are no pain management guidelines for NEC. We studied pain management in a cohort of neonates operated on for NEC in our hospital over a 5-year period.

Methods Data from 2008-2012 including COMFORTneo scores and analgesic treatment were retrieved from our patient data management system. COMFORTneo scores of 14 or higher and numeric rating scale pain score (NRS) of 4 or higher suggest pain or discomfort.

Results 69 neonates (29 boys, 40 girls) were operated on at median postnatal age 10 days (range $4-82$ days). The majority was Bell's stage $3(81.1 \%)$, gestational age ranged from 24.2 to 36.4 weeks. Twenty children (29\%) died, of whom 9 on day of surgery or the next day.

Conclusions Patients received relatively high doses of opioids leading to acceptable pain scores for such a painful condition. Benchmarking and prospective studies are necessary next steps.

\section{PO-0661 TRANSFER OF BEHAVIOURAL NEONATAL RESUSCITATION SKILLS LEARNT ON SIMULATOR IN THE SIMULATION ROOM TO CLINICAL PRACTICE IN THE DELIVERY ROOM}

${ }^{1} \mathrm{R}$ Vasa, ${ }^{2} \mathrm{~J}$ Bates, ${ }^{3} \mathrm{M}$ Henry. ${ }^{1}$ Pediatrics/Neonatology, Mercy Hospital and Medical Center and University of Chicago, Chicago, USA; ${ }^{2}$ Nursing, Mercy Hospital and Medical Center, Chicago, USA; ${ }^{3}$ Nursing, University of Illinois at Chicago, Chicago, USA

10.1136/archdischild-2014-307384.1302

Abstract P0-0660 Table 1

\begin{tabular}{|c|c|c|c|}
\hline Three moments of data collection: & 3 days before surgery & Day of surgery & 3 days after surgery \\
\hline Data collected & $\mathrm{N}=69$ & $N=69$ & $N=63$ \\
\hline $\begin{array}{l}\text { Fentanyl } \\
\text { Maximum dose }(\mathrm{mcg} / \mathrm{kg}) \\
\text { Maximum dose } / \text { day }(\mathrm{mcg} / \mathrm{kg})\end{array}$ & $\begin{array}{c}13.0 \% \\
2.1(1.9 \text { to } 2.2) \\
3.5(2.3 \text { to } 5.0)\end{array}$ & $\begin{array}{c}87.0 \% \\
3.2(2.3 \text { to } 4.8) \\
5.0(3.0 \text { to } 5.0)\end{array}$ & $\begin{array}{c}44.4 \% \\
2.0(1.8 \text { to } 3.1) \\
3.8(2.0 \text { to } 5.8)\end{array}$ \\
\hline $\begin{array}{l}\text { Morphine } \\
\qquad \text { Maximum dose/day }(\mathrm{mg} / \mathrm{kg})\end{array}$ & $\begin{array}{c}58.0 \% \\
0.24(0.14 \text { to } 0.43)\end{array}$ & $\begin{array}{c}95.7 \% \\
0.30(0.20 \text { to } 0.40)\end{array}$ & $\begin{array}{c}100.0 \% \\
0.43(0.27 \text { to } 0.54)\end{array}$ \\
\hline $\begin{array}{l}\text { Patients assessed } \\
\text { COMFORTneo score } \\
\text { Median (IQR) } \\
\text { NRS pain } \\
\text { Median (IQR) }\end{array}$ & $\begin{array}{c}10(9.5 \text { to } 11) \\
0(0 \text { to } 1)\end{array}$ & $\begin{array}{l}11 \text { (10 to } 12) \\
1(0 \text { to } 2.4)\end{array}$ & $\begin{array}{c}95.2 \% \\
11(10 \text { to } 12) \\
0(0 \text { to } 1)\end{array}$ \\
\hline $\begin{array}{l}\text { Number of assessments } \\
\text { COMFORTneo } \geq 14 \\
\text { NRS pain } \geq 4\end{array}$ & $\begin{array}{r}432 \\
9.5 \% \\
10.4 \%\end{array}$ & $\begin{array}{c}240 \\
18.7 \% \\
17.7 \%\end{array}$ & $\begin{array}{c}796 \\
16.5 \% \\
10.7 \%\end{array}$ \\
\hline
\end{tabular}

